Walisongo Law Review (Walrev), Vol 2 No. 1 (2020)

DOI: 10.21580/Walrev/2020.2.1.5321

Copyright (C) 2020 Walisongo Law Review (Walrev)

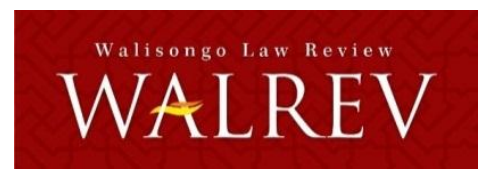

\title{
Analysis of the Causes of Narcotics Recidivities in Class IIa Prisons in Bogor
}

\author{
Yudha Nugraha Septiawan \\ Afiliasi: Politeknik Ilmu Pemasyarakatan (Poltekip), Depok \\ Email: yudhanugrahaseptiawan@gmail.com
}

\begin{abstract}
The risk can cause harm to someone, including people who have used narcotics. Drug abuse is a concern for many people today. Misuse of narcotics is a deviation of behavior or deeds that violate the law, and it is unfortunate if prisoners who are free to repeat the narcotics crime again. The problem that became the reference in this research is whether the factors that cause the repetition of narcotics crime, how the risk of repetition of narcotics crime, and how to overcome the narcotics crime repetition. The purpose of this study is to determine the factors, risks, and efforts in overcoming repetition of narcotics crime. This research was conducted using a qualitative approach by collecting data using interview, observation, and documentation methods. Data analysis is described in the form of sentence descriptions and analyzed qualitatively, then a conclusion is drawn. Based on the results of research and discussion, it is concluded: (1) Factors that influence the repetition of narcotics crime are internal factors and external factors. (2) The risk of repetition of narcotics crime is carried out in the level of risk classification. (3) Efforts to overcome the repetition of narcotics crime shall be carried out in a preventive and repressive manner. The advice given is maximizing rehabilitation activities
\end{abstract}


Yudha Nugraha Septiawan, Analysis of the Causes Narcotics Recidivities...

carried out in Corrections Institutions and maximizing coaching programs in Corrections Institutions

Risiko dapat menimbulkan kerugian pada seseorang, termasuk orang yang telah menggunakan narkotika. Penyalahgunaan narkotika saat ini telah menjadi sorotan masyarakat. Penyalahguaan narkotika dikatakan sebagai salah satu penyimpangan tingkah laku atau suatu perbuatan dimana melanggar hukum, dan sangat disayangkan jika narapidana yang sudah bebas melakukan perbuatan pengulangan tindak pidana narkotika lagi. Adapun permasalahan yang menjadi acuan didalam penelitian ini ialah apakah faktor-faktor penyebab residivis tindak pidana narkotika, bagaimana risiko terjadinya residivis tindak pidana narkotika, dan bagaimana upaya penanggulangan terhadap residivis tindak pidana narkotika. Tujuan penelitian ini ialah untuk mengetahui faktor-faktor, risiko-risiko, dan upaya dalam penanggulangan residivis tindak pidana narkotika. Penelitian ini dikerjakan dengan menggunakan pendekatan kualitatif dengan mengumpulkan data menggunakan metode wawancara, observasi, dan dokumentasi. Analisis data kemudian dideskripsikan menjadi uraian kalimat dan dianalisa secara kualitatif, kemudian ditarik suatu kesimpulan. Berdasarkan hasil penelitian dan pembahasan, maka disimpulkan: (1) Faktor-faktor yang mempengaruhi residivis tindak pidana narkotika adalah faktor internal dan faktor eksternal. (2) Upaya penanggulangan terhadap residivis tindak pidana narkotika dilakukan secara preventif dan represif. Saran yang diberikan yaitu memaksimalkan kegiatan rehabilitasi yang dilakukan di Lembaga Pemasyarakatan dan memaksimalkan program pembinaan yang ada di Lembaga Pemasyarakatan.

Keywords: Risk; Narcotics Misuse; Repetition.

\section{Introduction}

Risk is a part that can not be separated from everyday life, especially in carrying out a job. We also do not know what will happen in the future, it could be that what was previously planned in the implementation failed, which did not match what was expected and it 
turns out that our prediction was not the same as what was expected. When the failure arises due to various factors that caused it, and in the end we only get the risk of loss, both directly and indirectly in various forms.

Risk is defined as an event that is faced by a person or company which can get a loss. Likewise in prison, all forms of activities in it certainly contain risks that will be faced and must be addressed, so that in the future does not cause fatal losses. The amount of the loss due to the risk faced varies greatly depending on the causes and effects.

If only the risk is easy to know with certainty both the shape and amount, then of course this can be treated like a cost because the risk is an uncertainty it will become an important problem for all parties (Mc Neil, 1999). But an effort to reduce or minimize risk can still be done by carrying out a risk control against uncertainty such as work accidents, natural disasters, robberies, theft and bankruptcy (Muslich, 2007).

The risk also causes harm to someone, including people who have used narcotics. Drug abuse is currently in the spotlight today. Many people are already familiar with narcotics, both adults, adolescents, and even minors who are familiar with these illicit goods. It turns out that this narcotics circulation has penetrated everywhere regardless of age. Narcotics are part of a type of drug drugs, substances or substances that when entered into the body that can affect brain function, namely the central nervous system and cause dependence. Where there is a change in awareness, thoughts, feelings, and behavior of users.

In Law Number 35 of 2009 concerning Narcotics in Article 1 Paragraph (1) that narcotics are substances or drugs originating from plants or non-plants, both synthesis and semi-synthesis that can cause a decrease or change in consciousness, loss of taste, reduce to eliminate pain, so that it can cause dependence, which is divided into groups as attached in this law. At present the dangers and impacts of narcotics and drugs on life and health in society are increasingly 
troubling. Where narcotics are like two sides of a coin, narcotics can provide benefits and can also damage health. There are many types of drugs which enter into the type of drug used for the healing process because it causes a calming effect. However, if used with excessive doses can cause addiction to the wearer.

Based on the Narcotics Law, it is known that it is possible for a narcotics offender to be sentenced to a maximum, that is, he can be sentenced to death other than imprisonment and in fines or compensation. It is known that narcotics crimes fall into the specific types of criminal offenses, then criminal threats against them can be dropped cumulatively with two main types of criminal acts at the same time, namely imprisonment and fines or capital punishment and fines. The narcotics criminal category includes addicts, dealers, and users.

Dealers and addicts are two things that are interconnected. Addicts today many people use narcotics not for medical purposes but for the comfort of themselves and trends. This is very sad because in Indonesia most teenagers abuse narcotics. Data on narcotics abuse by teenagers in August 2019 by the Head of the National Narcotics Agency (BNN) Commissioner General of Police Heru Winarko said that narcotics abuse among adolescents is increasing, where an increase of $24 \%$ to $28 \%$ of teenagers who use narcotics.

Narcotics abuse committed is a deviation of behavior or violates the law. BNN states that the abuse and distribution of narcotics in the community shows an increase with the spread of victims due to drugs (Jakarta, Kompas.com, Wednesday, June 26, 2019 "BNN Calls Abuse and Circulation of Narcotics Increasing"). World Drugs Reports 2018, published by the United Nations Office on Drugs and Crime (UNODC), states as many as 275 million people in the world or $5.6 \%$ of the world's population (aged 15-64 years) at this time have ever consumed drugs. While in Indonesia, $\mathrm{BNN}$ as the focal point in the field of Prevention and Eradication of Drug Abuse and Circulation ( $\mathrm{P} 4 \mathrm{GN})$ pocketed the number of drug abuse in 2017 as many as $3,376,115$ people in the age range of $10-59$ years. While in 2018 , the 
prevalence of drug abuse among students in 13 provincial capitals in Indonesia reached $3.2 \%$ or equivalent to 2.29 million people.

Data on Penitentiary Guides (WBP) of narcotics crime in Indonesia totaled 123,337 people in October 2019, this data was taken from smslap.ditjenpas.go.id. It is unfortunate if drug convicts who have finished carrying out their criminal sentences are free then repeat the drug crime again and go to prison again. The term repetition of this crime is known as "recidivist".

As an example of a repeat of a narcotics crime that occurred in Salatiga, Central Java on September 14, 2019. The Salatiga Police Narcotics Unit arrested two people who used methamphetamine drug abuse on Jalan Pramuka No.61 Krajan RT o8 / RW 05, Sidorejo Village, Salatiga City on September 14, 2019. Salatiga Police Chief Adjunct Senior Commissioner Gatot Hendro Hartono said that the two suspects were known to be recidivists of narcotic crime.

According to Gatot AKBP, both were based on confession to officers accustomed to consuming methamphetamine and previously the suspect had served time in prison for a similar case with a sentence of around two years. He claimed to use methamphetamine since 2017 and had been caught by police. Then in the trial, sentenced to one year and four months in prison. He admitted that he had only been released a month ago and returned to using methamphetamine because of association (Tribun Jateng, 20 September 2019).

Examples of other real cases regarding recidivities of narcotic crime are those that occurred in Muara Teweh, Central Kalimantan. Supriansyah alias Anggut (34) was arrested while taking methamphetamine drugs at his residence on Jalan Imam Bonjol RT 26B Muara Teweh, North Barito Regency, Central Kalimantan. The suspect turned out to have been arrested twice in connection with this drug case first in 2018 and then on September 27, 2019. The suspect was then charged with Article 112 paragraph (1) Jo Article 127 paragraph (1) of RI Law No.35 of 2009 concerning Narcotics (Antaranews, 28 September 2019). 
The existence of these cases, it can be seen the factors causing recidivities of narcotics crime due to addiction, negative relationships and the economy where they make a living by selling drugs. Countermeasures against both penal and non-penal measures have been carried out such as counseling, rehabilitation, and imprisonment. But there are still cases of repetition of narcotics crimes. Regarding rehabilitation activities in Penitentiaries (Lapas), not all prisons have rehabilitation activities. This is due to constraints related to the budget to carry out the rehabilitation activities.

A person who has committed a narcotic crime must be sentenced to imprisonment. The purpose of imprisonment is to protect the community and improve their lives. Basically, this law aims to create conditions in a social life, both in a small environment and in a larger environment, so that there is harmony, order, legal certainty, etc. (PAF Lamintang, 1997: 16) .

The Criminal Code (KUHP) in which there are regulations relating to criminal matters, which at present is still a basic provision of criminal law in Indonesia, which is to guarantee legal certainty. In the justice system in Indonesia, criminal law is currently one of the concerns of various parties, especially the public. The implementation of integrated criminal justice is one of the main principles in the judiciary in Indonesia, with the recognition of the principle of "equality before the law". In reality, the implementation of this principle is only community oriented, that is, where the community is one of the parties involved in criminal cases, both as witnesses, perpetrators, and victims, especially for those who are subject to the status of a suspect, defendant or convict, where the principle should also be oriented towards law enforcement officers especially judges.

The stage of criminal punishment or conviction is now an important matter for us to highlight, why is that because the punishment is the end of a case in a criminal case, where the decision of a judge can make someone found guilty or innocent in breaking the law and will subsequently be charged or was convicted or could be free from the law. Quoted from "Muladi and Barda Nawawi Arief, 1984: 91" the punishment is as one part of the criminal law 
enforcement mechanism and can also be interpreted as a means of giving crime, which becomes a planned policy process. The granting of this criminal can be realized because previously it had been planned through several stages, namely the stage where the determination of the crime was determined by the legislators; the stage where the granting of the crime was given by the authorized body; and the stage where the implementation of a crime is carried out by an implementing agency that has been given authority.

Criminalization is known as a part of the last effort in the existing criminal law enforcement process and is also the end or the culmination of the whole system which moves people to conduct certain behaviors as expected by the community. Criminalization is also a tool for the process of imprisonment, which must be done carefully, and the need for that accuracy to be considered related to the criminal that is in accordance with the condition of the defendant. And it is known that the granting of a criminal is not the same as one another, because the criminal becomes a thing that can change.

In recent times it is often heard that prisoners who are undergoing training or incarcerated in a prison, apparently can still control their crimes from inside the prison wall. Regarding the unsuccessful in handling narcotics crimes, where prisoners who are undergoing criminal imprisonment in prison in fact are still able to carry out or control narcotics crime also from within the Prison, the following news can be seen:

Thursday, August 1, 2019 Detective Unit (Satres) Cimahi Police Narcotics succeeded in uncovering a narcotics distribution network that was allegedly operated from within the Class IIA Narcotics Prison in Bandung (Jelekong). Cimahi Police Chief, AKBP Rusdy Pramana Suryanagara said five people were arrested including a prisoner of Class IIA Narcotics Prison in Bandung. Rusdy explained that the disclosure of drug control in the Class IIA Narcotics Prison in Bandung originated from the arrest of a courier with the initials CR carrying narcotics of methamphetamine type in Rajamandala Village, Cipatat, West Bandung (KBB). Developed again, eventually capturing the army in Haruwangi, Cianjur. Then the two suspects claimed that the narcotics belonged to DK who was still serving detention in the 
Yudha Nugraha Septiawan, Analysis of the Causes Narcotics Recidivities...

Class IIA Narcotics Prison in Bandung. The police then collaborated with the Bandung Class IIA Narcotics Prison and in the end got another piece of evidence in the form of a cell phone unit. From the results of the deepening, it revealed the BoC controlled the circulation of methamphetamine and cannabis from the Class IIA Narcotics Prison in Bandung through $\mathrm{AD}$ and $\mathrm{CR}$ intermediaries. Rusdy explained that the perpetrators communicated using cellphones to circulate narcotics"

(Kamis, 1 Agustus 2019 Satuan Reserse (Satres) Narkoba Polres Cimahi berhasil mengungkap jaringan pengedar narkotika yang diduga dioperasikan dari dalam Lapas Narkotika Kelas IIA Bandung (Jelekong). Kapolres Cimahi, AKBP Rusdy Pramana Suryanagara mengatakan lima orang berhasil dibekuk termasuk satu tahanan Lapas Narkotika Kelas IIA Bandung. Rusdy menjelaskan pengungkapan pengendalian narkoba di dalam Lapas Narkotik Kelas IIA Bandung itu berawal dari tertangkapnya seorang kurir berinisial CR membawa narkotika jenis sabu di Desa Rajamandala, Cipatat, Bandung Barat (KBB). Dikembangkan lagi, akhirnya menangkap AD di Haruwangi, Cianjur. Kemudian kedua tersangka mengaku narkotika itu milik DK yang masih menjalani tahanan di Lapas Narkotika Kelas IIA Bandung. Polisi kemudian bekerja sama dengan pihak Lapas Narkotika Kelas IIA Bandung dan pada akhirnya mendapatkan barang bukti lainnya berupa satu unit ponsel. Dari hasil pendalaman, pihaknya mengungkapkan DK mengendalikan peredaran sabu dan ganja dari dalam Lapas Narkotika Kelas IIA Bandung melalui perantara AD dan CR. Rusdy mennjelaskan para pelaku tersebut berkomunikasi menggunakan ponsel untuk mengedarkan narkotika" (Tribunnews, 1 Agustus 2019).

"Head of the Central Kalimantan National Narcotics Agency (BNNP), Brigadier General Lilik Heri Setiadi suspected that methamphetamine which was successfully secured as much as 350 grams from a man with the initials AL (29), was deliberately brought from Java. The methamphetamine will be circulated in East Kotawaringin Regency and in the Sampit City Class II Lapas. Strong suspicion that in addition to the East Kotawaringin region, methamphetamine was also sold in the Class IIB Lapit in Sampit City. The allegations arose after officers arrested several other networks, one of which was a Class IIB 
Yudha Nugraha Septiawan, Analysis of the Causes Narcotics Recidivities...

Lapas Lapas employee. As well as an inmate who controls the methamphetamine was imported from Java. From these activities, officers managed to secure four drug networks, one of which came from outside the island of Kalimantan. The four perpetrators named as suspects had the initials AL, KT (33), Sampit City Class IIB Lapas employees, DE (22) Sampit residents and NR (39) an inmate in the Sampit City Class IIB Lapas as controlling and ordering illicit goods. "

"Kepala Badan Narkotika Nasional Provinsi (BNNP) Kalimantan Tengah Brigjen Pol Lilik Heri Setiadi menduga sabu-sabu yang berhasil diamankan seberat 350 gram dari seorang pria berinisial AL (29), sengaja dibawa dari Pulau Jawa. Sabu itu akan diedarkan di Kabupaten Kotawaringin Timur dan di dalam Lapas Kelas IIB Kota Sampit. Kuat dugaan selain di wilayah Kotawaringin Timur, sabu tersebut juga dijual di dalam Lapas Kelas IIB Kota Sampit. Dugaan itu muncul setelah petugas menangkap beberapa jaringan lainnya yang salah satunya adalah oknum pegawai Lapas Kelas IIB Kota Sampit. Serta seorang narapidana yang menjadi pengendalian sabu-sabu tersebut didatangkan dari Pulau Jawa. Dari kegiatan itu, petugas berhasil mengamankan empat orang jaringan narkoba yang salah satunya berasal dari luar Pulau Kalimantan. Keempat pelaku yang sudah ditetapkan sebagai tersangka tersebut berinisial AL, KT (33), pegawai Lapas Kelas IIB Kota Sampit, DE (22) warga Sampit dan NR (39) seorang narapidana di Lapas Kelas IIB Kota Sampit sebagai pengendali sekaligus pemesan barang haram tersebut” (Republika.co.id, 20 Maret 2019)

Then sad about the control of drugs from within this prison, BNN states that 90 percent of drug transactions are controlled from within prison. This disclosure was quoted from the Merdeka.com news that:

"The head of the National Narcotics Agency (BNN) of RI Komjen Pol Heru Winarko said 90 percent of drug transactions in all regions of Indonesia are controlled from Lapas. According to him, Lapas is considered to be a safe place for dealers to control the circulation of illicit goods. Heru said, the cause was due to weak supervision in prison. He said the ease with which drug dealers control drugs from prison cannot be separated from the role of naughty wardens. Finally, he is willing to provide facilities for bookies to communicate with networks outside" 
Yudha Nugraha Septiawan, Analysis of the Causes Narcotics Recidivities...

"Kepala Badan Narkotika Nasional (BNN) RI Komjen Pol Heru Winarko mengatakan 90 persen transaksi narkoba di seluruh wilayah Indonesia dikendalikan dari Lapas. Menurutnya, Lapas dianggap menjadi tempat aman untuk para bandar mengendalikan peredaran barang haram tersebut. Heru menuturkan, penyebabnya karena lemahnya pengawasan di Lapas. Dia menyebut mudahnya bandar narkoba mengendalikan narkoba dari Lapas tidak lepas dari peran sipir nakal. Akhirnya, dia rela menyediakan fasilitas untuk para bandar berkomunikasi dengan jaringan di luar" (Merdeka.com, 18 September 2019).

From the news above it can be concluded and it is known that although prisoners who are convicted in prison in prison, they still control the drug network both via cellphones and from prison officers as well. Such a situation is of course a concern, is there something wrong with the criminal implementation process and guiding prisoners in prison so far. Indeed related to the issue of law enforcement can not only be seen from the standpoint of the law, but also must be seen in full by involving all the elements that exist, such as morals, behavior, and culture. Therefore, the need for a new orientation and perspective in law enforcement (Mahrus Ali, 2010: 210-229).

Based on the background outlined above, the writer will examine the risk factors for recidivating narcotics crime. Therefore researchers conducted research related to "Analysis of Narcotics Criminal Recidivities in Class IIA Prisons in Bogor".

The objectives in this study are (1) to find out the factors that cause a repeat of the misuse of narcotics crime; (2) to find out the risks that can cause a repeat of the misuse of narcotics crime; and (3) actions taken in tackling repetition of misuse of narcotic crime.

\section{Research methods}

The problem approach used in this study is a qualitative approach, which is research in which produces a descriptive data in the form of words written or spoken from the people observed and observed behavior. Descriptive in the sense of providing a description of the 
phenomena that are carried out in accordance with scientific methods (I.S.Santo, 1990: 15).

In this study, collecting data to support the research process using interviews, observation and documentation. Interviews were conducted with officers and prisoners with narcotics cases, both recidivists and non-recidivists. This documentation by studying documents to obtain data and information to be included in research through articles, journals, and the internet related to research topics. The results obtained after the identification of the data are then compiled and analyzed using qualitative methods based on theories and principles relating to the subject matter studied (Lexy J.Moleong, 2004: 103)..

\section{Research result}

\section{Factors Causing the Repetition of Narcotics Crimes}

Repetition of narcotics misuse can be done by anyone, both women and men, at the age of children, adolescents, adults, and elderly. Crimes can also be done consciously, semi-consciously, or unconsciously. Someone who has committed a crime must be motivated by a cause and factors that exist. To find out the factors that cause a person to repeat a narcotic crime, the author uses the theory put forward by Abdul Syani in his book "Sociology of Mathematics, Theory, and Applied", namely internal factor theory and external factors.

\section{Internal Factors}

Internal factors are factors that originate from a person or individual itself. Internal factors that cause a person to repeat narcotics crime are individual factors and psychological factors. Where in each individual or individual must have a great curiosity about something new. This curiosity causes a person to want to try narcotics, where after trying and then knowing the taste which makes it comfortable and addictive, then the person will repeat his actions using narcotics.

In psychological factors there is the term egostrength which is the ability where a person is able to deal with the pressure he 
receives. When a person faces a severe pressure, he will find a way or somehow he can reduce the pressure, where he can move the pressure to a simpler such as narcotics, so that the person becomes no longer stressed or the problem can disappear and he feels comfortable on him.

Rehabilitation activities in prisons for prisoners of narcotics cases are aimed at prisoners who take part in rehabilitation when they are free, when they are no longer dependent on narcotics or do not know about narcotics anymore, but in reality there are those who abuse narcotics again and eventually go to prison again. The author considers that they repeat the abuse of narcotics criminal acts because of the heavy pressure on them, so they use narcotics again so that they are not stressed.

From interviews that were conducted to 59 people who were recidivist Prisoners (WBP), where $20 \mathrm{WBP}$ people were taken as samples. The results obtained from the interview were that some of them stated that they repeated the abuse of narcotics again because they were stressed. This stress is triggered because they are left free by their wives and children, so they have to use drugs again to relieve their stress. And also the stress is caused in the past where they are when there is a problem and to relieve that stress they use drugs. So that after being released from prison and when they have a problem that makes them stressed, they repeat their previous habit of using drugs to repeat the string.

\section{External Factors}

External factors are factors that are in the environment outside of human beings. The influence of external factors is what leads to criminal acts of narcotics abuse, namely environmental factors, religious factors and economic factors. After the author conducted an interview with the WBP who is a recidivist of narcotics abuse crimes from the results of these interviews the authors get data that the factors that lead to them are environmental factors, religious factors, and economic factors. These environmental factors lead to friends in the neighborhood where prisoners live 
Yudha Nugraha Septiawan, Analysis of the Causes Narcotics Recidivities...

and work. From interviews conducted, most inmates repeat narcotics crimes due to friends. This friend who goes with prisoners using narcotics, both those who teach and friends accompany when using drugs. So it can be said, wrong association can lead to negative activities and habits, which violate legal and religious norms. So it is better in associating to sort out friends who are both personalities and religions, who can invite us to positive activities.

Religion can be a social control, which can determine a human behavior in accordance with existing religious values. And if religion does not function well for humans, it will only be a symbol or cover, so that it will not mean anything at all. Even human faith will be weak and can easily do bad things because the social control was not strong. So even though the prisoner has attended rehabilitation and the time is free out there, if his faith is not strong because he is still dependent on narcotics because he wants to be comfortable, then he will use narcotics again and also if invited by friends to use narcotics because his faith is weak then he will follow the invitation of his friend. From the results of interviews conducted, it is known that some of them repeat the narcotics crime again because of an invitation from friends to use narcotics.

In this economic factor most of the prisoners who are free to repeat narcotics crime again due to economic problems. Where they have not gotten a job and in the past they got money from selling narcotics, so they returned to selling narcotics to get money to meet their daily needs. From the results of the interviews that have been conducted. Most of them repeat the crime of drug abuse due to economic problems.

\section{Countermeasures against Narcotics Criminal Acts Recidivises}

The recidivist crime of narcotics abuse raises a lot of unrest in the community, where the recidivist criminal act of narcotics abuse is due to the many factors that influence the occurrence of the crime. The 
existence of these factors, then efforts must be taken to overcome these criminal factors. Efforts to deal with recidivating drug abuse, the authors use the theory of crime prevention, namely preventive and repressive efforts.

\section{Preventive Efforts}

Through preventive measures that are preventive (preventive) there are steps both internally and externally. The main objective of this preventive effort is to improve certain social conditions that do not directly affect the prevention of crime. In the effort to deal with recidivities, this narcotics misuse is through a small matter first, namely from the family environment.

Families where those closest to them (narcotics abuse) can provide support and supervision so that they are monitored and get motivated so that they do not repeat criminal acts of narcotics abuse again. This monitoring can be done by limiting or prohibiting them from associating again with their previous friends who made them familiar with narcotics. And providing support from the family is very important, this is so that their hearts can melt let alone give support from parents or loved ones (wife or husband). The role of the family here is very important, therefore the beginning of this prevention starts from the family. Because in the interview that has been done, the writer in the interview asked them "whether the family is very important to them" and from the whole answer is very important because they are very dear and need their family.

Then the preventive measures carried out are given positive activities to them, so that they can forget about the name narcotics because they are preoccupied with the activities they do. And also directed them back to the right path and strengthened their religion, so that their faith is strong and always remember God. Regarding narcotics dealers, they are given motivation so that they can get decent work (halal) and instill a sense of gratitude to them for their fortune. This is so that they do not make money through selling/distributing narcotics again. 


\section{Repressive Efforts}

Repressive efforts are carried out by applying criminal measures against recidivists of narcotics abuse crimes. In addition to criminal application, another effort is rehabilitation that aims to treat and restore the physical, psychological, mental, moral and social conditions of victims of narcotics abuse and to prevent the disease from recurring and reoccurring. For rehabilitation activities in Class IIA Prison Bogor has been given.

Roni Darmawan, as the Head of Guidance Section for Prisoners and Students in Class IIA Prison in Bogor, stated that in prison related to efforts to deal with crime here is known as coaching that is repressive. Coaching efforts are made to return prisoners to the community or known as social reintegration, so that prisoners are useful in the community and are accepted again. Coaching is said to be twofold namely fostering independence and fostering personality.

This self-help fostering is given to them so that they have the provision of expertise and there are activities in prison. It also aims to make them not bored and expected to forget narcotics. For spiritual personality development, religious guidance is done so that they are aware of their actions that have been done and always remember God, with the hope that they will not repeat the same or new crime in the future.

\section{Conclusion}

Based on the results of research and discussion that has been done, the writer can draw the conclusion that:

1. The factors that cause recidivities of criminal acts of narcotics abuse there are two factors, namely internal factors and external factors. Internal factors include individual factors and psychological factors. This individual factor in every individual there is a great curiosity about something new so they want to try to use narcotics, where after trying to find out the taste and make it comfortable and addictive, then someone will repeat their 
Yudha Nugraha Septiawan, Analysis of the Causes Narcotics Recidivities...

actions using narcotics. Psychological factors about a person are under such great pressure that he must avoid them. So, to avoid the pressure, he uses narcotics to reduce or eliminate the pressure.

External factors include environmental factors, religious factors, and economic factors. This environmental factor in the environment of residence or workplace where friends influence them to use narcotics. Religious factors are weak in them, where their faith is weak and they forget their God so they repeat the abuse of narcotics again. The economic factor is that after they are free, there are no jobs and to fulfill their daily needs, which used to sell narcotics, they are forced to return to doing the work

2. Efforts to deal with recidivating narcotic crime are carried out to overcome repetition of narcotic criminal acts through preventive and repressive measures. Preventive efforts can be done through the family by giving motivation or support so that they do not repeat acts of narcotics again and supervision by giving restrictions / prohibitions to get along with friends who once had a bad influence on them. And also given a positive activity so that they do not remember the narcotics that are caused by the activity, and strengthen their religion so that their faith is strong and always remember God. And instill a sense of gratitude for the fortune they get from halal work.

Repressive efforts are carried out, namely the application of crimes against recidivists of narcotic abuse and the application of rehabilitation which aims to treat and restore the physical, psychological, mental, moral and social conditions of victims of narcotics abuse and to prevent the disease from recurring and reoccurring. In Class IIA Prison, Bogor, repressive efforts are carried out in the form of fostering activities both fostering independence and fostering personality, with the aim that when they are free they will have expertise and they will always remember God with hope that they will not repeat the same or new crimes in the future. [] 
Yudha Nugraha Septiawan, Analysis of the Causes Narcotics Recidivities...

\section{Reference}

Ali, M. 2010. "Sistem Peradilan Pidana Progresif: Alternatif dalam Penegakan Hukum Pidana." Jurnal Hukum No. 2 Vol. 14 April 2007.

https://bnn.go.id/penggunaan-narkotika-kalangan-remajameningkat/

http://antaranews.com/residivis-narkotika-ditangkap-polisi-dimuara-teweh/

http://tribunjateng.com/belum-kapok-juga-residivis-pengguna-sabukembali-di-tangkap-polisi-beli-lewat-napi-rutan/

http://kompas.com/BNN-sebut-penyalahgunaan-dan-peredarannarkotika-semakin- meningkat/

http://smslap.ditjenpas.go.id/

http://m.tribunnews..com/polisis-ungkap-peredaran-narkoba-yangdikendalikan-dari-lapas-jelekong/

http://www.m.republika.co.id/berita/nasional/umum/19/o3/20/poo 2t4384-sabusabu-diduga-beredar-di-lapas-sampit/

http://m.merdeka.com/bnn-9o-persen-transaksi-narkobadikendalikan-dari-dalam-lapas/

Lamintang, P. 2017. "Sistem Peradilan Pidana Progresif: Alternatif dalam Penegakan Hukum Pidana." Jurnal Hukum No.2 Vol.14.

Moleong, L. 2004. Hukum Penitensier Indonesia. Bandung: Remaja Rosdakarya.

Muladi and Barda Nawawi Arief. 1984. Teori-Teori dan Kebijakan Pidana. Bandung: Alumni.

Peraturan Pemerintah Nomor 31 Tahun 1999 tentang Pembinaan dan Pembimbingan Warga Binaan Pemasyarakatan.

Rahman, Y. S. 2018. "Mekanisme Pembatasan Pembiayaan Rehabilitasi Terhadap Narapidana Residivis Penyalahgunaan 
Yudha Nugraha Septiawan, Analysis of the Causes Narcotics Recidivities...

Narkotika." Public Knowledge Project Negara dan Keadilan, Vol.7 No.2.

Rezza, M. F. 2018. "Analisis Kriminologis Terhadap Residivis

Kejahatan Penyalahgunaan Narkoba." Jurnal Poenale, Vol.6 No.5.

Susanto, I. 1990. Kriminologi. Semarang: Fakultas Hukum UNDIP.

Syani, A. 1987. Sosiologis Kriminalitas. Bandung: Remaja Karya.

Sutanti, R. D. 2017. "Kebijakan Aplikatif Pemberatan Pidana Bagi Pelaku Pengulangan Tindak Pidana." Indonesian Journal of Criminal Law Studies II , (1).

Undang-Undang Nomor 12 Tahun 1995 tentang Pemasyarakatan.

Undang-Undang Nomor 35 Tahun 2009 tentang Narkotika. 